\title{
Spanish and British Teacher Trainees on Exchange in Primary Schools Abroad: an Intercultural Experience in Educational Settings
}

\author{
RAMiro DurÁn MARTíneZ \\ University of Salamanca
}

Received: 20 November 2009 / Accepted: 16 May 2010

ISSN: 1697-7467

\begin{abstract}
This paper focuses on the international exchange placement of the primary teachers' training programme fostered through the agreement signed between the Spanish MEC and the English TDA. More specifically, as international teaching practice provides an exceptional opportunity for developing the intercultural dimension, the aim of the paper is to analyse the responses to the intercultural component central to the teaching placement of students from both countries as part of their training in the host country. Our analysis will be based on the information obtained from questionnaires that British and Spanish students answered at the end of their placement in foreign schools.

Keywords: International Teaching Practice, Intercultural Dimension, Primary Education, Exchange Placements.
\end{abstract}

Intercambio de futuros maestros españoles y británicos en el extranjero: Una experiencia intercultural en contextos educativos

RESUMEN: Este artículo analiza las prácticas internacionales de los programas de formación del profesorado de primaria fomentados a través del acuerdo firmado entre el MEC español y la TDA inglesa. Más concretamente, ya que las prácticas docentes internacionales proporcionan una oportunidad excepcional para el desarrollo de la dimensión intercultural, el objetivo del artículo reside en analizar las respuestas al componente intercultural central a las prácticas docentes de los estudiantes de ambos países como parte de su formación en el país anfitrión. Nuestro análisis se basará en la información obtenida a través de los cuestionarios que los estudiantes británicos y españoles respondieron al final de su estancia en los centros extranjeros.

Palabras clave: Prácticas Docentes Internacionales, Dimensión Intercultural, Educación Primaria, Intercambios de Prácticas Docentes.

\section{The CONTEXT OF THE PROJeCt OF International TeACHING PRACTICE}

The UK-Spanish programme to foster international teaching practice in primary schools started in November 2003 with the agreement signed between the Spanish Ministry of Education and Science (MEC: Ministerio de Educación y Ciencia) and the Teacher and Development 
Agency (TDA) from the Department for Education and Skills of the United Kingdom ${ }^{1}$. The main aim of this agreement was to cooperate jointly both in the field of teacher training and in the area of foreign language teaching in primary education. The programme was so successful that in just two years 13 Spanish and 15 British universities were participating in a programme which has allowed over 200 students per year enrolled in teaching training programmes in both countries to travel to overseas schools to do their compulsory teaching practice for a period of four weeks.

Our current international teaching practice experience has arisen from a long established relationship between Nottingham Trent University and the University of Salamanca, which has resulted in a range of joint educational initiatives in pre-service and in-service teacher training. This has led to close and productive links between educational institutions in both countries: mainly primary schools, local educational authorities, university departments and lecturers and teachers' centres. Among the different co-operation programmes, the following can be highlighted: Teaching practice (Practicum I \& II) in Nottingham primary schools carried out by students enrolled in teacher training at the University of Salamanca for periods of 4 to 6 weeks; intensive tailor-made courses delivered in Spain, within the TDA 500 Teachers Project, for groups of primary school teachers from Nottingham about aspects of language, culture and education in Spain, with a practical component in primary schools; development of both an Erasmus Cooperation Programme permitting student mobility between the two universities and Socrates mobility programmes for teaching staff; the joint publication of a bilingual teaching practice guide (Durán et al 2006); an educational project of story-sacks in primary schools, with school correspondence and exchange of materials, together with mutual visits of teachers of both countries to their school partners; collaboration of different lecturers from both institutions in joint papers presented at national and international forums and in different publications, giving an account of the development of this and similar initiatives.

This co-operation network has culminated in the current project of international teaching practice involving the University of Salamanca Schools of Education of Avila and Zamora and the Nottingham Trent University Faculty of Education, with the effective collaboration of the Nottingham Local Education Authority (LEA). The present partnership allows fifteen Spanish trainees to travel every year to British primary schools to do their compulsory teaching practice (Practicum I or II) for a period of four weeks, while fifteen British PGCE (Postgraduate Certificate in Education) students have the opportunity of completing an equivalent four week training placement in schools in Spain. Thus, the agreement signed between the Spanish Ministry of Education and Science and the English TDA to foster international teaching practice in primary schools has added important qualitative changes to a long and productive relationship that was initiated more than ten years ago. Above all, the university students of both countries have been given an extraordinary incentive, as they have received financial and academic backing for their aspirations, and the exchange of experiences, visits and perspectives of children, teachers, educators and collaborating institutions have been extended.

When implementing this international teaching practice experience various difficulties need to be overcome, mainly concerning the differences between the British and the Spanish models of educational training for MFL (Modern Foreign Languages) primary teachers. The first one is that British PGCEs receive a more general preparation whereas the Spanish trainees

1. In 2003 the Spanish MEC was called the Ministry of Education, Culture and Sports (MECD) while the British TDA was called the Teacher Training Agency (TTA). 
have some degree of specialization. A second difference is that while most Spanish students are young with little or non-existent working or travel abroad experience, British students tend to be more mature and possess a broader working and visits abroad experience. In the third place, in order to access the teacher training programme, Spanish students are exclusively required to pass Bachillerato (A levels) while British students should have completed an undergraduate university course and are selected by a process of presentations and interviews. Fourthly, the length of the training programme is also different: while the Spanish undergraduate training course is three years long the British is a one year long postgraduate programme. Regarding their teaching placement, Spanish students are required to complete a Practicum I (four weeks of generalist practice) and a Practicum II (6 weeks of MFL - Modern Foreign Languages - specialist practice in the UK or Spain). British students are required to complete their Link Practice Plus (5 weeks placement prior to their placement abroad), four weeks of teaching practice in Spain and an eight-week long Final Placement.

These differences between the two models of educational training will help explain some of the answers to the questionnaire about intercultural communication as they imply an average of a four year age difference between the Spanish and the British trainees.

\section{The intercultural Dimension OF LANGUAge TeACHing: From COMMUNICATIVE COMPETENCE TO INTERCULTURAL COMPETENCE}

It is nowadays widely recognized that the purpose of the curriculum in the area of foreign languages for primary education is to learn to communicate successfully, to varying degrees, in a second language. The different legal frameworks that regulate educational practice in Spain $^{2}$ and in the $\mathrm{UK}^{3}$ acknowledge the primacy of communication within the area of foreign languages based on the needs of today's society: the project of a European community, citizen mobility, the new information and communication technologies, and the forming of a spirit that is tolerant towards other forms of culture and at the same time aware of its own identity. These new situations contribute to orienting language teaching towards the acquisition of communicative competence, not only for instrumental purposes but also for cultural understanding.

The communicative approach has meant a change both in the way language is conceived and in the objectives pursued in the teaching of a second language, giving priority to the ability to use the language within growingly complex social and cultural milieus. Indeed, intercultural skills and abilities are becoming an ever more important objective in the area of language teaching abroad, as shown in the Common European Framework of Reference for Languages: Learning, Teaching, Assessment (2001), hereafter CEF, currently considered an indispensable tool for any joint initiatives in the education and language fields among the countries in Europe. Besides fostering transparency in courses, programmes and qualifications at a European level, the CEF also pursues political and intercultural objectives such as increasing international

2. Spain: Royal Decree 1513/2006, of 7 December 2006 (Official State Gazette, 8 December 2006) for primary education and Royal Decree 1631/2006, of 29 December 2006 (Official State Gazette, 5 January 2007) for secondary education.

3. The National Languages Strategy for England [http://www.dfes.gov.uk/languagesstrategy/]; The Key Stage 2 Framework for Languages, Department for Education and Skills, England, UK. Date of Issue: 10/2005. Ref: 1721-2005DCD-EN [http://www.standards.dfes.gov.uk/primary/publications/languages/framework/] 
mobility, the promoting of mutual understanding and tolerance, respecting the identities and cultural diversity of the member States, the satisfaction of socio-economic needs in a multilingual Europe, etc.

The CEF itself defines intercultural knowledge as the awareness, knowledge and understanding of the relationship (similarities and differences) between the student's own culture and the culture pertaining to the second language community. The task of language teachers is not only to develop the linguistic competence of their students, but also to develop and foster their intercultural competence, with positive attitudes and values towards specific countries and cultures:

Intercultural Competence is achieved through a relational process where the learner is required to place the host culture in relation to one's own. This does not involve the transmission of cultural information, rather, it involves a reflection and a dialogue between both cultures (Zarate, 1995; Kramsch 1993). Language learners are not mere processors of information, but cultural beings who need to build bridges from the known to the unknown. This is a two-way communication system where both cultures are going to be affected by it. Such communication demands an attitude of respect, of understanding and openness, which accepts that one's own assumed cultural patterns are not going to be left intact. (Gutiérrez Almarza and Ros i Solé, 2005: 24)

This intercultural competence comprises the development of intercultural skills, preparation for interaction with individuals and social groups of other cultures, understanding different perspectives, values and behaviour, overcoming prejudice and stereotypes and appreciating diversity as an enriching human element and a factor in democracy and citizen maturity.

As Byram (2002) puts it, language teaching is nowadays closely linked to the different modalities of «knowing» that accompany the competencies strictly related to language as shown in the following table ${ }^{4}$ :

\begin{tabular}{|c|l|}
\hline Intercultural attitudes & $\begin{array}{l}\text { curiosity and openness, readiness to suspend disbelief about other cultures } \\
\text { and belief about one's own; or the ability to 'decentre' and thus gain } \\
\text { different perspectives and understand diverse points of views. }\end{array}$ \\
\hline Knowledge & $\begin{array}{l}\text { of social groups and their products and practices in one's own and in one's } \\
\text { interlocutor's country, and of the general processes of societal and } \\
\text { individual interaction of distant peoples and cultures converging within } \\
\text { shared geographies and common political scenarios. }\end{array}$ \\
\hline $\begin{array}{c}\text { Skills of interpreting } \\
\text { and relating }\end{array}$ & $\begin{array}{l}\text { the ability to interpret a document or event from another culture, to explain } \\
\text { it and relate it to a document or event from one's own. }\end{array}$ \\
\hline
\end{tabular}

4. Adapted from Michael Byram et al (2002) Developing the Intercultural Dimension in Language Teaching: A Practical Introduction for Teachers, pp. 12-13. 


\section{INTERNATIONAL TEACHING PRACTICE AS INTERCULTURAL TRAINING}

International teaching practice provides an exceptional opportunity for developing the intercultural dimension in the training of teachers specialized in a foreign language. For reasons that are easily understood, and normally attributed to the nature of programmes and examinations, our teaching intervention in the university classroom generally focuses on the development of knowledge and skills linked to the target language rather than on reflection about the attitudes and values related to the culture(s) of the second language.

Nevertheless, in Training confident primary modern foreign language teachers in England: An investigation into pre-service teachers' perceptions on their subject knowledge (2008), Woodgate-Jones concludes, for the practicum abroad, regardless of the age and possible prior experience of the students, it is necessary to prepare their stay in another country and in another school system so that they can take full advantage of the overall educational experience. For many students, it is the first time they find themselves in an unknown environment where they can put into practice all their abilities, and not only those relating to language, in order to carry out the work they have to do. To prepare them, Byram (2002) recommends using learning by experience, which is defined in the following way:

The study visit or exchange is an opportunity to promote 'savoir être'. This is best done through experiential learning, where learners can experience situations which make demands upon their emotions and feelings and then reflect upon that experience and its meaning for them, thus combining the affective and the cognitive. The teacher's role is to structure the learning experience, to ensure that the 'culture shock' is productive and positive, and not overwhelming and negative, and to help learners to analyse and learn from their responses to a new environment. (Byram, 2002: 19)

Furnham (1993) and Woodgate-Jones (2008) highlight the importance of the practicum abroad experience in the training of primary MFL teachers. According to Woodgate-Jones' findings, obtained through the analysis of interviews and questionnaires completed by preservice teachers belonging to eighteen different British education institutions:

Confidence in both linguistic competence and intercultural understanding (but particularly the latter) rose sharply after the period of practicum abroad. By the end of the course a very small minority of preservice teachers rated themselves as less than four (out of ten) in either linguistic competence or intercultural understanding. (Woodgate-Jones, 4: 2008)

Byram and Doyé (1999) have also argued that it is only possible to attain an advanced level of communicative competence through fieldwork and this is particularly the case for intercultural competence. In order to support the idea that the practicum abroad experience is vital they strongly recommend that primary school language teachers should have the same obligatory «year abroad» as secondary school language teachers. 


\section{Aims and scope of our Research}

The analysis of the ideas, dilemmas, perspectives and experiences of the trainees has thrown light upon this international teaching practice project. Becoming a teacher in two educational contexts involves being subject to different experiences and new challenges. The benefits of this kind of placement have been pointed out in other contexts as it helps the trainees to reflect upon their own school culture but also to appreciate the cultural differences in another school context (Newman, E. et al 2004, Ortega and Madrid 2006, Woodgate-Jones 2008). We will examine, then, the different responses to the intercultural component central to the four week placement that students from both universities carry out as part of their training in the target country.

Our findings will be based on the 16 items of a questionnaire that both sets of students answered after having completed their exchange placement abroad. These were divided into four different headings:

a) Linguistic, cultural and intercultural experience

b) Pre-intercultural experience

c) Self-assessment of your Teaching Practice

d) Self Assessment of your intercultural experience ${ }^{5}$

A total of 45 students (25 Spanish and 20 British) answered this questionnaire. As already mentioned in the first section of our paper, due to the existing differences between the Spanish and the British model of educational training for primary teachers of a second language, there is a relevant age difference between the British and the Spanish group of students participating in our research: while the average age of the British students is 27 , the average age of the Spanish students is 23 .

\section{Ages of students participating in our research}

British students: 22 (3), 23 (2), 24, 25 (6), 26, 27, 29 (2) 32, 35, 36, 44 Average: 27

Spanish students: 20 (2), 21 (9), 22 (3), 23 (4), 25 (4), 28 (2), 38 Average: 23

In our comparative analysis, we will mainly draw our findings from the answers which give the most relevant information for our aim: a reflection on the intercultural component of the four week teaching practice placement abroad.

\section{Data analysis}

The Annex will provide the whole wording of the questionnaire items whose results will be briefly summarized in the following sections: for a further explanation of the variables used see Durán, R., Gutiérrez, G. y Beltrán, F. (2006).

5. The appendix includes an abridged version of the questionnaire published in the International Guide for Placement Abroad in Primary Schools (2006), Durán, Beltrán \& Gutierrez. Ediciones Universidad de Salamanca. 135-144. 


\section{Part A: Linguistic, Cultural and Intercultural Experience}

In this section of the questionnaire, British and Spanish trainees answered questions concerning their current level of English/Spanish, their knowledge of other foreign languages, their motivation to learn English/Spanish and the background of their knowledge of English/ Spanish.

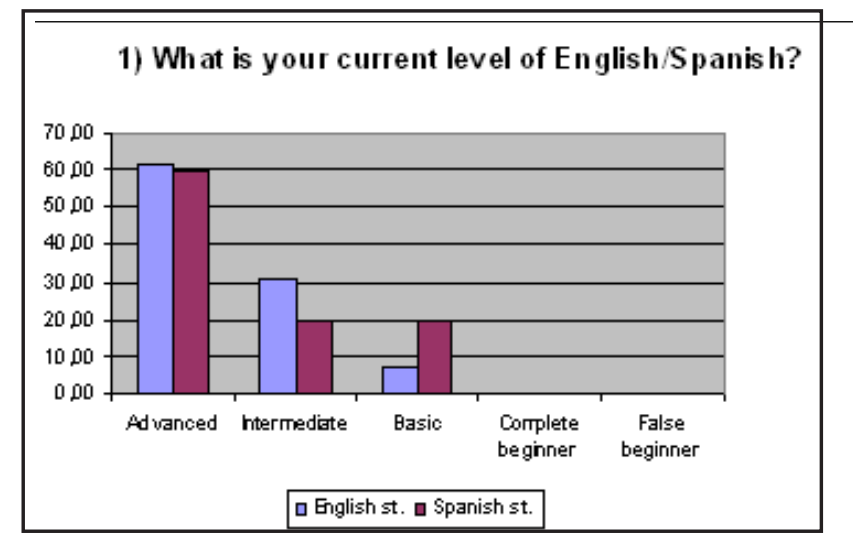

As can be seen in Chart 1, the British students, who are generally older and have broader travelling experience, show a better command of the L2 than the Spanish students: 91 per cent of the British students (versus 80 per cent of the Spanish students) define their level as «Advanced» or «Intermediate». The answers to the second item of our questionnaire also highlight that the British students seem to be more used to learning more than one foreign language than the Spanish students: 92 per cent of British students (versus 62 per cent of Spanish students) speak another foreign language, apart from Spanish. This can be partly explained by the predominant role of English as a second language in the Spanish education system. Nowadays, English is considered as a world language (McArthur, 2002) or even as a global lingua cultura (Phillipson, 2003) being promoted as an L2 by every country in the western world while Spanish is, together with German and French, just one of the three most popular foreign languages in the British education system.

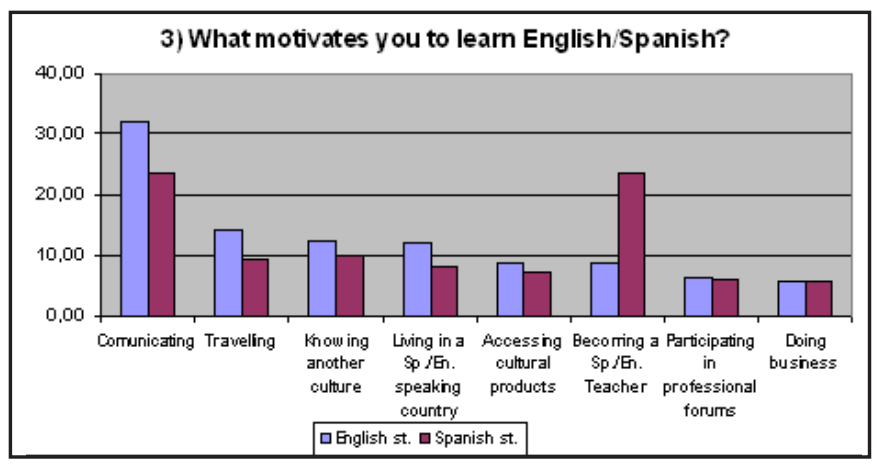


When motivation is examined (Chart 3), while some similarities emerge - the main aim when learning a language is «to communicate with native speakers» even though neither groups of students is «business» oriented - some relevant differences are also made evident: 23 per cent of the Spanish students, versus 8 per cent of the British students, want to learn English to become an English teacher while the British students seem to be more interested in travelling (14 per cent versus 10 per cent of the Spanish students) or even living in a Spanish speaking country (12 per cent versus 9 per cent of the Spanish students). In Spain, the predominant role of English as a foreign language in all the stages of the educational system enables trainees to consider becoming an English teacher as a feasible job prospect, particularly in the stages of infant and primary education where, in recent years, there has been a considerable increase in the number of posts available both in state and in public schools. The answers to this item of the questionnaire show that while Spanish trainees are mainly motivated to learn a language owing to the prospect of becoming an English teacher, British trainees attach more importance to culturally-relevant factors such as comunicating with Spanish people, travelling, getting to know another culture better, living in a Spanish speaking country or accessing cultural products in Spanish.

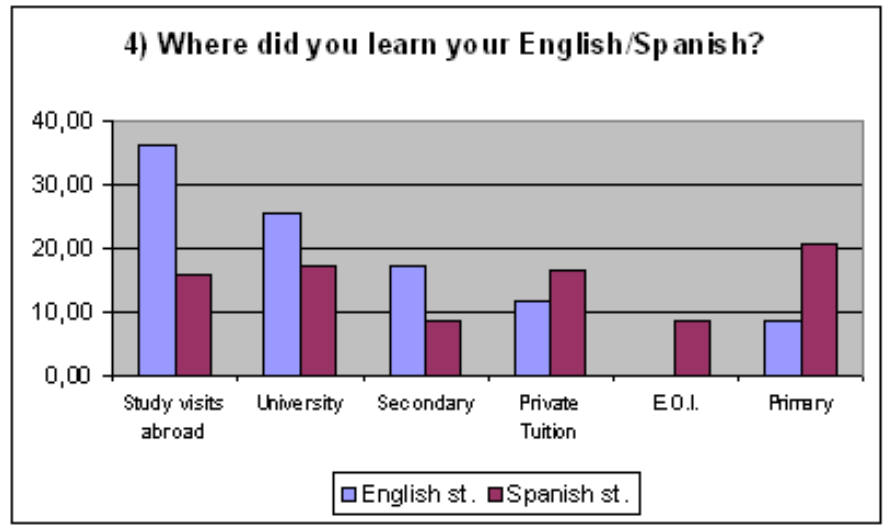

As shown in chart 4, primary education, official schools of languages (non-existent in the U. K.), and private tuition are perceived as the most important settings to learn a foreign language by Spanish students while the stages of secondary education and university are considered more useful by British students. Until very recently, the role of second languages in English primary schools has been really poor. This situation is bound to change in the near future due to the so-called National Languages Strategy for England which is committed to increasing the nation's language capability. The cornerstone of this plan is the introduction by the year 2010 of an entitlement to language learning for every pupil in Key Stage 2 (ages 711 years $)^{6}$.

On the contrary, primary education is perceived as a relevant stage for language learning by the Spanish trainees. Certain measures in the Spanish educational policy such as the early

6. Documents concerning the National Languages Strategy Languages for all Languages for life can be downloaded at www.teachernet.gov.uk/publications 
introduction of English in the stage of infant education or the considerable increase in the number of primary schools with content and language integrated programmes will definitely make these early stages even more inportant in the near future.

Study visits abroad also seem to play a larger role when learning a foreign language for the British students (36 per cent) as compared with the Spanish students (16 per cent). This substantial difference might be partly explained by the importance granted to the study visits abroad in British educational culture and particularly in the language training programmes at British universities: every programme of educational training for MFL primary teachers in the UK involves a compulsory period of practicum abroad to develop both the trainee's linguistic abilities and their intercultural understanding. Spanish trainees, on the contrary, are not formally required to spend any time abroad during their training programme at University. In Britain, secondary school language teachers have a compulsory year abroad as part of their training and, as shown in the third section of our paper, there are those who recommend that primary school language teachers should also have an obligatory year abroad to boost both their linguistic and intercultural competence. This broader visits abroad experience on the part of British trainees will be reflected on the answers to the next item of the questionnaire.

\section{Part B: Pre-intercultural Experience}

In this section, British and Spanish trainees answered questions concerning their own perception on the sources of their knowledge of English/Spanish culture, aspects of English/ Spanish culture which made them feel uncomfortable, and whether their TP had been the first time they had travelled abroad.

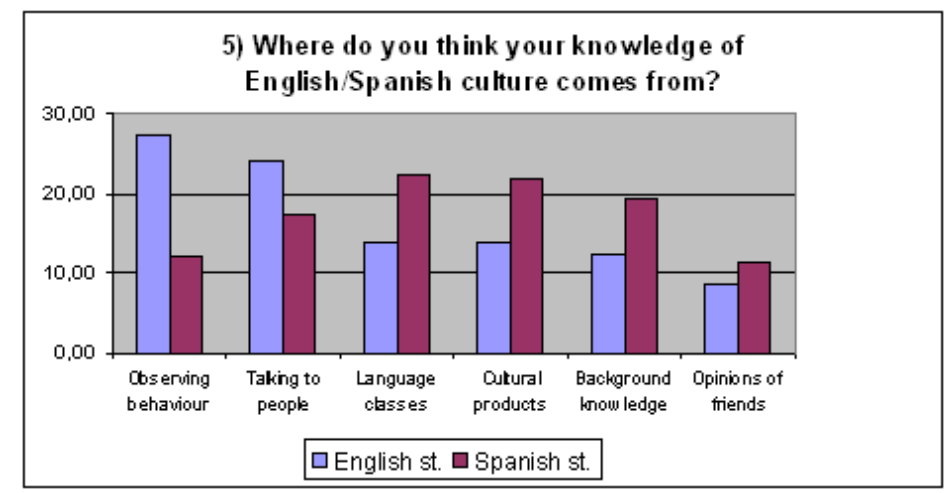

When asked question number five «Where do you think your knowledge of English/ Spanish culture comes from?» British students tend to give more importance to direct contact with Spanish-speaking people: their main resources for cultural knowledge come from observing Spanish speaking people's behaviour and customs (27 per cent) and talking to Spanish speaking people (24 per cent). On the other hand, the Spanish students tend to rely more on indirect contact with the L2, such as language classes (22 per cent) and cultural products ( 21 per cent). These data should be directly linked with the answers provided for the previous question and question number 8 «Was your teaching experience the first time you went abroad?»: 71 per 
cent of the Spanish students had never been abroad before their teaching practice experience while all the British students had already been to a foreign country.

In the answer to question number $\operatorname{six}^{7}$ «What aspects of English/Spanish culture do you find most different from your own culture?» 60 per cent of both sets of students agree on considering schedules (particularly regarding meals), food (with highly differing opinions on the matter) and schools as the aspects most different from their own culture. Regarding Spanish schools, the British trainees mainly highlight aspects related to classroom management and discipline: i.e. a closer relationship between teachers and students, the lack of uniforms, the fact that Spanish teachers are called by their first name and the existence of less pressure for staff education. Spanish trainees perceive differences in aspects related to classroom layout and innovative didactic approaches: i.e. English classes are more colourful, teachers do not use coursebooks, every teacher uses a very rich bank of materials, etc. The role of families in society is also regarded as different by most of the students in both groups: 25 per cent of the British students highlight the importance of family in Spain while 30 per cent of the Spanish trainees regard British families as much more independent than families in Spain.

The most relevant fact about question number seven «Do any aspects of English/Spanish culture make you feel uncomfortable?» is that approximately 70 per cent of both the British and Spanish students did not find any negative aspect about their target culture. Those British trainees who found negative elements mentioned the treatment of animals, the high amount of meat in diets and religious devotion while all the Spanish trainees who found a negative aspect of their target culture mentioned British food.

\section{Part C: Self-assessment of your Teaching Practice}

In this section, British and Spanish trainees provided answers to questions about their reasons for doing their teaching practice in Spain/England, the greatest adaptation difficulties they found and the steps they thought their teachers in Spain/England should take to best prepare them for their TP abroad.

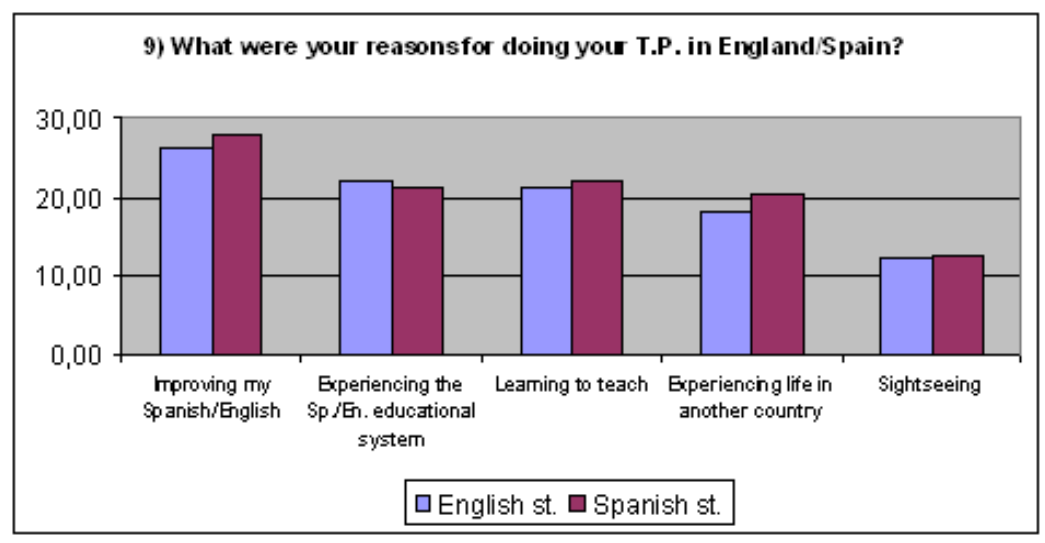

7. Questions number 7, 8 and all the questions from part D of the questionnaire are open questions. Consequently the trainees' answers will not be accompanied by a chart. 


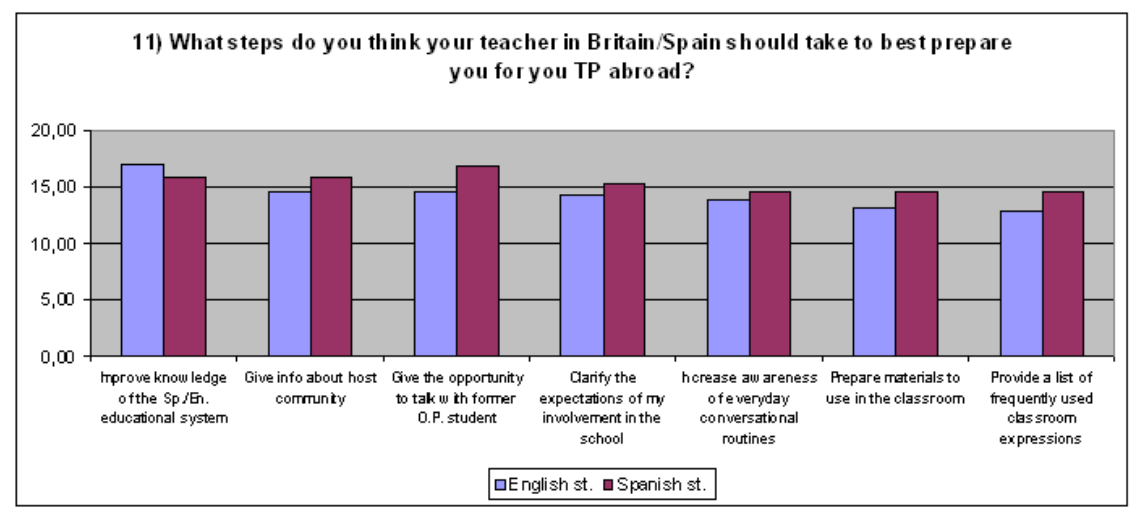

Very similar answers in both groups of students are shown in some questions from this section of the questionnaire: mainly the reasons for doing their teaching practice abroad (see chart nine) - the most frequently alleged reasons being, in this same order, improving their command of the language, experiencing a different educational system and learning to teachand the steps University teachers should take to best prepare them for their teaching practice abroad (question number 11): both sets of students agreed on considering the three most important elements to be: 1) the improvement of their knowledge of the other country's educational system, 2) the opportunity to talk with former trainees who participated in this programme and, 3) to have information about the host community and surrounding area in advance. They also regarded the provision of a list of frequently used classroom expressions, the increase in their awareness of everyday conversational routines and the preparation of sets of materials and activities to take and use in the classroom in advance as the least important aspects for their teaching practice preparation.

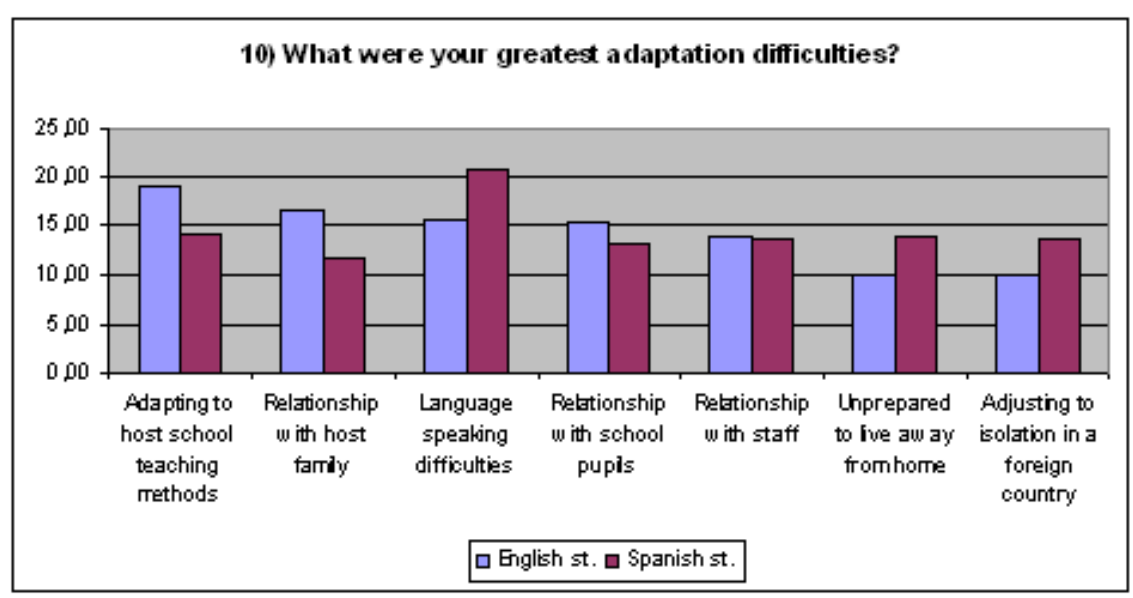


Regarding the differences between the two groups, analysis of Chart 10 shows that «Adapting to host school teaching methods» was the main difficulty for British students during their teaching practice while «Language Speaking Difficulties» was perceived as their main problem by Spanish students. On the other hand, the difficulties of adjusting to isolation in a foreign country and being unprepared to live away from home are greater for the Spanish students, while the relationship with host family and with school pupils seem to be more difficult for the British students.

As this international teaching practice experience may be the first time abroad for Spanish trainees, the academic goals accompanying their objectives of cultural assimilation and psychological adaptation are much broader. Increasing their independence and self-confidence in every aspect of this practicum abroad experience - linguistic, social, pedagogical, personal and psychological - is the main challenge for the Spanish trainees. Surprisingly, regardless of their language speaking difficulties, they find it easier than the British trainees to build a relationship with their pupils and their host families.

\section{Part D: Self Assessment of your intercultural experience}

In this section, British and Spanish trainees were invited to mention important facts about the Spanish/English way of life, to reflect on whether learning about the other culture may help them question their own cultural practices, to say if they had witnessed any misunderstanding arising from people's lack of awareness of the viewpoint of another culture, and to identify strategies to enhance their cultural awareness of the target country, providing examples where possible.

This part of the questionnaire is based on open questions so the trainee answers are not accompanied by a chart. In answer to the question related to their knowledge of Spanish/ English-speaking cultures «Have you noticed any important facts about living in Spain and the people living there?» the British trainees singled out as the most interesting elements, in the following order: 1) the importance of family, tradition and culture, 2) the Spanish attitude to work considering it as «not the most important thing in life» and 3) the existence of different communities and provinces in Spain, all of them quite different from each other. On the other hand, the Spanish trainees highlighted the importance of cultural minorities, the fact that English people are not as distant as they are stereotypically represented in the media and the bad behaviour of groups of young people at night contrasting with the good behaviour of young people in the morning as the most surprising facts about their daily life experience in the U.K.

The response of both groups of students to the next question, «Do you think that learning about the other culture helps you question your own cultural practices?» is directly linked with their teaching practice experience. The British trainees mainly mentioned aspects such as the way teachers approach behaviour and organization in the classroom, the fact that in Spain parents and children are seen as more responsible for the child's learning and the questioning of the «blame» culture for teachers in Britain. On the other hand, the Spanish trainees mentioned the innovative methodologies used by teachers in the UK and the use of many different teaching materials and resources (not only coursebooks). Most of the Spanish trainees also highlight that English teachers work really hard after school carefully planning their classes well in advance. As a teacher trainer, it is worth highlighting that answers to this question really show that both the British and Spanish trainees are definitely aware of how being immersed in a different culture puts their own cultural practices into question. 
Question number fourteen is related to their knowledge of intercultural communication «Have you witnessed or experienced any misunderstandings that arise from people's lack of awareness of the viewpoint of another culture?» and the answers can be illustrated through some quotes from our trainees after their school immersion abroad. These answers reflect personal and real experiences, most of them representing the sentiments of many trainees:

\section{BRITISH STUDENTS}

* I have been with people who have been discussing bull fighting and not been able to come to an agreement. It was very difficult to resolve because it is a subject that both parties are passionate about.

* I couldn't understand Easter processions. At first some friends thought it was morose and morbid.

* We had a discussion with a man who would not believe that Great Britain was part of the European Union. He believed that we did not want to be European. We explained to him the real facts but he needed some persuasion. His misunderstanding was that just because we didn't have the Euro we did not want to be part of the E.U.

\section{SPANISH STUDENTS}

* It was difficult for them to understand that I don't like eating sandwiches for lunch.

* I had some difficulties when greeting. English people greet you by shaking hands. They don't kiss to greet.

* I thought English people said «box» when they wanted to say «bus». The accent of Nottingham can sometimes be difficult.

The information obtained from question number fifteen «Which of the following do you do to discover new information and new aspects of Spanish culture by yourself?» is consistent with the answer given to question five: when learning about a new culture by themselves, the British students tend to rely more on direct contact with Spanish speaking people - i.e. actively seeking people to practise the language and visit Spain as much as possible- while Spanish students give more importance to the use of cultural products: i.e. reading as much as possible in English, listening to music in English or watching English speaking TV or films.

The answer to item sixteen, regarding the relationship between their linguistic level and cultural competence, "Give an example of an instance where your limited knowledge of English/Spanish made it difficult for you to understand a cultural issue» is different in each set of students: while the British students seem to be quite confident with Spanish and only experience communication problems when talking about complex political or legal issues «I couldn't understand Plan Ibarretxe» or particular lexical items: «Bocadillos. I thought it meant sandwiches. I didn't know it meant speech bubble too», some Spanish students experience communication problems with more practical issues such as arriving at their destination by bus, ordering food in a restaurant, watching an English film without subtitles or staff room conversations.

As a way of synthesizing the most relevant data from the questionnaire, the results shown in Part A (Linguistic, Cultural and Intercultural Experience), show that British students are generally older, have a better command of the L2, are more used to learning more than one foreign language and have a broader study visits abroad experience than Spanish students. Students' intercultural experience prior to the Teaching Practice period (Part B) also shows how Spanish students rely more on indirect contact with the L2 to get to know English culture 
(mainly language classes and cultural products) while British students give more importance to direct-contact with Spanish-speaking people.

From their self-assessment of their teaching practice (Part C), very similar answers are shown regarding the reasons for doing their teaching practice abroad and the steps teachers should take to prepare them for their TP abroad. Adapting to host school methodology, relationship with host family and with school pupils were the main difficulties for British students while language speaking difficulties was the main problem for their Spanish counterparts. Surprisingly, regardless of these difficulties, Spanish students find it easier to build a relationship with pupils and host families. As shown in the analysis of part D of the questionnaire, the self assessment of their intercultural experience helped trainees to reflect on aspects of their daily life experience in their host country, on their difficulties to understand some cultural issues and particularly on their teaching practice experience. Generally speaking, and regarding their intercultural experience, British students attach more importance to culturally-relevant factors such as communicating with Spanish people, travelling, improving their knowledge of the target culture or accessing cultural products in Spanish.

\section{Conclusion}

The main aim of this article was to analyse the intercultural component in the exchange placement abroad of the primary teachers' training programme run by the Schools of Education of the universities of Salamanca and Nottingham Trent. After having provided some relevant contextual clues for our study and once the answers to both sets of questionnaires have been analysed, we can conclude that the different profiles of the students in each country, with regard to age, prior experience in foreign stays, cultural, linguistic and academic background are decisive in determining the nature of the impact of their school placement abroad.

We perceive that the age factor counteracts the predominant role of English as a foreign language in all the stages of the Spanish education system: due to their higher linguistic competence, British students tend to have less communication problems and consequently they find it easier to access cultural knowledge. The broader experience in foreign stays on the part of the British students also conditions their main resources for cultural knowledge, most of it coming from direct contact with Spanish-speaking people. Again, this broader experience has been made possible by the formation schemes of their universities of origin, which include stays abroad as part of their academic training.

On the contrary, Spanish students rely more on indirect contact with the British culture. Motivation to learn a foreign language is also different between the two sets of students: while the Spanish trainees are mainly motivated by the pragmatic factor of becoming an English teacher, the British trainees attach more importance to culturally-relevant factors. This is also consistent with their institutional background. Whereas Spanish students come from a threeyear university degree, most British students are postgraduate students who complete their teacher training programme after many different academic or professional routes, often alien yet complementary to the world of education.

As a consequence, one of the main differences between the groups of students is that, for British students, their insertion into Spanish schools represents a change of the framework but not a redefinition of the standards previously defined at Nottingham Trent University, allowing them to focus on academic, linguistic and microcultural aspects since they have 
already been exposed to former macrocultural immersion experiences. On the contrary, for students from the University of Salamanca, teaching practice may be their first experience abroad and the academic goals accompanying their objectives of cultural assimilation and psychological adaptation tend to be much broader: the challenge of completing their practicum abroad has manifold consequences ranging from integrating their previous learning experiences in a live cultural context to boosting their self-confidence in themselves allowing them to face future visits abroad confidently. Therefore, the responsibility for effective exposure to relevant intercultural experiences in teacher training needs to be considered as a shared objective both by the host and the guest institutions - fostering this or similar stay abroad visits, links or exchanges, beneficial to their educational agendas - and by the individual students who need to integrate these personal, cultural, educational and linguistic challenges within their experiential portfolio and professional profile.

\section{BibliographiCAL REFERENCES}

Byram, M. \& Doyé, P. (1999). «Intercultural competence and foreign language learning in the primary school», in The teaching of modern foreign languages in the primary school. $\mathrm{P}$. Driscoll \& D. Frost (eds.) London: Routledge.

Byram, M. et al. (2002). Developing the Intercultural Dimension in Teaching. A Practical Introduction for Teachers. Language Policy Division, Strasbourg: Council of Europe Publishing.

Durán, R. Gutiérrez, G. \& Beltrán, F. (2006). Guía internacional de prácticas docentes en centros de educación primaria / International Guide for Placement Abroad in Primary Schools. Salamanca: Ediciones Universidad de Salamanca.

Furnham, A. (1993). «Communicating in foreign lands: The cause, consequences and cures of culture shock», in Language, Culture and Curriculum, 6, 1: 91-109.

Gutiérrez Almarza, G. \& Ros i Solé, C. (2005). «Developing ICC with Beginner University Language Learners», in IALIC Annual Conference, Brussels (in press).

McArthur, T. (2002). The Oxford Guide to World English. Oxford: Oxford University Press.

Newman, E. et al. (2004). "'You just can't do it like that -it's just wrong!' Impressions of French and English trainee primary teachers on exchange placement in primary schools abroad: the value of experiencing the difference», in European Journal of Teacher Education, 27, 3: 285-298.

Ortega, J. \& Madrid, D. (2006). «A Framework for Teaching Practice in the European Context», in The International Journal of Learning, 13, 7: 133-143.

Phillipson, R. (2003). English-Only Europe? Challenging Language Policy. London and New York: Routledge.

Woodgate-Jones, A. (2008). «Training confident primary modern foreign language teachers in England: An investigation into pre-service teachers' perceptions on their subject knowledge», in Teaching and Teacher Education, 24, 1-13.

Common European Framework for Languages: Learning, Teaching, Assessment (2001). Council for Cultural Cooperation Education Commitee. Language Policy Division. Strasbourg, available from http://www.coe.int/t/dg4/linguistic/CADRE EN.asp, accessed 18 October 2009.

The Key Stage 2 Framework for Languages, Department for Education and Skills, England, UK. Date of Issue: 10/2005, available from: http://www.standards.dfes.gov.uk/primary/publications/ languages/ framework/, accessed 18 October 2009. 


\section{ANNEX - QUESTIONNAIRE \\ PART A: LINGUISTIC, CULTURAL AND INTERCULTURAL EXPERIENCE}

\section{Bio-data:}

Name:

Age:

Nationality:

1) What is your current level of English? Tick one of the boxes below.

Complete beginner

False beginner

Basic

Intermediate

Advanced

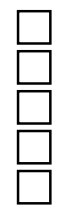

2) Do you speak other language (s)? Tick one of the boxes below.

Yes (if yes, go to question 3)

No

3) What motivates you to learn English? Rank the following areas (1 being the area that interests you most and 8 the least).

- Communicating with English people

- Becoming an English teacher

- Doing business with English-speaking firms

- Traveling to English-speaking places

- Participating in professional forums

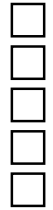

- Accessing a variety of cultural products/sources (i.e. articles, books, films, magazines, etc.)

- Getting to know another culture better

- Living in an English-speaking country

- Other (please specify) :

4) Where did you learn your English? Close to 1 for a lot and close to 5 for not at all.

- Primary

- Secondary

- E.O.I.

- Study visits abroad

- Private tuition

- $\quad$ Other (please specify) : 


\section{PART B: PRE-INTERCULTURAL EXPERIENCE}

5) Where do you think your knowledge of English culture comes from? Rank the following areas ( 1 being the area that interests you most and 6 the least)

- Cultural products (books, films, the media, etc.)

- Background knowledge and education (e.g. general knowledge about history)

- Language classes

- Opinions of other friends

- Talking to English-speaking people

- Observing English-speaking people's behaviour and customs

Other (please specify):

6) What aspects of English culture do you find most different from your own culture? Make a list.

7) Do any aspects of English culture make you feel uncomfortable? Make a list.

8) Was your Teaching Practice Experience the first time you went abroad?

Yes $\square$ No

\section{PART C: SELF-ASSESSMENT OF YOUR TEACHING PRACTICE}

9) What were your reasons for doing your Teaching Practice in England? Close to 1 for a lot and close to 5 for not at all.

- Improving my English

- Experiencing the English Educational System

- Learning to teach

- Experiencing daily life in another country

- $\quad$ Sightseeing

Other (please specify):

10) What were your greatest adjustment/adaptation difficulties? Close to 1 for a lot and close to 5 for not at all.

- Adapting to host school teaching methods

- $\quad$ Language/speaking difficulties 
- Unprepared to live away from home

- Relationship with host family

- Relationship with school pupils

- Relationship with staff

- Adjusting to isolation in a foreign country

Other (please specify):

11) What steps do you think your teachers in Spain should take to best prepare you for your Teaching Practice Abroad? Close to 1 for a lot and close to 5 for not at all.

- Give information about the host community and surrounding area in advance

- $\quad$ Provide a list of frequently used classroom English expressions

- Increase my awareness of everyday conversational routines

- Give the opportunity to talk with former Overseas Project trainees

- $\quad$ Prepare in advance sets of materials/activities to take and use in the classroom in advance

- Clarify the aims and expectations of my involvement in the school in advance (tasks, materials production, observing/assisting/teaching time)

- Improve my knowledge of the British Educational System prior to my Teaching Practice

Other (please specify):

\section{PART D. SELF ASSESSMENT OF YOUR INTERCULTURAL EXPERIENCE}

12) Have you noticed any important facts about living in England and the people living there? Tick a box below and, if appropriate, give an example of some new facts that you have learned:

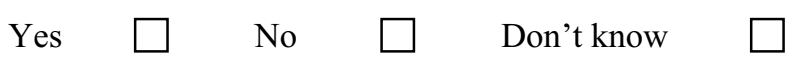

Please give an example:

13) Do you think that learning about the other culture helps you question your own cultural practices? Tick a box below and, if appropriate, give an example of a situation when this has happened. 
Yes $\square \quad$ No $\square \quad$ Don't know $\square$

Please give an example:

13) Do you think that learning about the other culture helps you question your own cultural practices? Tick a box below and, if appropriate, give an example of a situation when this has happened.

Yes $\square \quad$ No $\square \quad$ Don't know

Give an example:

14) Have you witnessed or experienced any misunderstandings that arise from people's lack of awareness of the viewpoint of another culture? Tick one of the following boxes and, if appropriate, give an example of a misunderstanding that you have witnessed and tried to resolve.

Yes $\square \quad$ No $\square \quad$ Don't know

Could you give us an example?

15) Which of the following do you do?

- Actively seeking people to practise the language (native speakers, fellow students or others).

- $\quad$ Try to read as much as possible in the foreign language

- $\quad$ Listen to music in English

- Watching English speaking TV or films.

- Using the internet in English, Others:

16) Give an example of an instance where your limited knowledge of English made it difficult for you to understand a cultural issue.

MANY THANKS FOR TAKING THE TIME TO FILL IN THIS QUESTIONNAIRE 